\title{
Biogenic, anthropogenic and sea salt sulfate size-segregated aerosols in the Arctic summer
}

\author{
Roya Ghahreman ${ }^{1, \mathrm{i}}$, Ann-Lise Norman ${ }^{1}$, Jonathan P. D. Abbatt ${ }^{2}$, Maurice Levasseur ${ }^{3}$, and \\ Jennie L. Thomas ${ }^{4}$ \\ ${ }^{1}$ Department of Physics and Astronomy, University of Calgary, Calgary, Canada \\ ${ }^{2}$ Department of Chemistry, University of Toronto, Toronto, Canada \\ ${ }^{3}$ Department of Biology, Laval University, Québec, Canada \\ ${ }^{4}$ Sorbonne Universités, UPMC Univ. Paris 06, Université Versailles St-Quentin, CNRS/INSU, UMR8190, LATMOS-IPSL, \\ Paris, France \\ i previously published under the name Roghayeh Ghahremaninezhad
}

Correspondence to: Ann-Lise Norman (alnorman@ucalgary.ca)

Received: 12 December 2015 - Published in Atmos. Chem. Phys. Discuss.: 4 February 2016 Revised: 8 April 2016 - Accepted: 15 April 2016 - Published:

\begin{abstract}
Size-segregated aerosol sulfate concentrations were measured on board the Canadian Coast Guard Ship (CCGS) Amundsen in the Arctic during July 2014. The objective of this study was to utilize the isotopic composition of sulfate to address the contribution of anthropogenic and biogenic sources of aerosols to the growth of the different aerosol size fractions in the Arctic atmosphere. Non-seasalt sulfate is divided into biogenic and anthropogenic sulfate using stable isotope apportionment techniques. A considerable amount of the average sulfate concentration in the fine aerosols with a diameter $<0.49 \mu \mathrm{m}$ was from biogenic sources $(>63 \%)$, which is higher than in previous Arctic studies measuring above the ocean during fall $(<15 \%)$ (Rempillo et al., 2011) and total aerosol sulfate at higher latitudes at Alert in summer ( $>30 \%$ ) (Norman et al., 1999). The anthropogenic sulfate concentration was less than that of biogenic sulfate, with potential sources being long-range transport and, more locally, the Amundsen's emissions. Despite attempts to minimize the influence of ship stack emissions, evidence from larger-sized particles demonstrates a contribution from local pollution.

A comparison of $\delta^{34} \mathrm{~S}$ values for $\mathrm{SO}_{2}$ and fine aerosols was used to show that gas-to-particle conversion likely occurred during most sampling periods. $\delta^{34} \mathrm{~S}$ values for $\mathrm{SO}_{2}$ and fine aerosols were similar, suggesting the same source for $\mathrm{SO}_{2}$ and aerosol sulfate, except for two samples with a relatively high anthropogenic fraction in particles $<0.49 \mu \mathrm{m}$ in diameter (15-17 and 17-19 July). The high biogenic frac-
\end{abstract}

tion of sulfate fine aerosol and similar isotope ratio values of these particles and $\mathrm{SO}_{2}$ emphasize the role of marine organisms (e.g., phytoplankton, algae, bacteria) in the formation of fine particles above the Arctic Ocean during the productive summer months.

\section{Introduction}

Climate is changing in the Arctic faster than at lower latitudes (IPCC, 2013), and it has the potential to influence the Arctic Ocean and aerosols that form above it. The Arctic Ocean is considered a source of primary aerosol, such as sea salt and organics, as well as secondary particles from the oxidation of $\mathrm{SO}_{2}$ to sulfate $\left(\mathrm{SO}_{4}^{2-}\right)$ (Bates et al., 1987; Charlson et al., 1987; Andreae, 1990; Yin et al., 1990; Leck and Bigg, 2005a, b; Barnes et al., 2006; Ayers and Cainey, 2007). Aerosols drive significant radiative forcing and influence climate directly (by the scattering of short- or long-wave radiation) and indirectly (by changing the number and size of cloud droplets and altering precipitation efficiency) (Shindell, 2007). Recently, it has been shown that their net effect is cooling the Arctic, which offsets around $60 \%$ of the warming effect of greenhouse gases (Najafi et al., 2015). However, there are key uncertainties in the estimation of aerosol effects and their sources which arise from limited information on their spatial and temporal distribution. 
Sulfate in the Arctic atmosphere originates from anthropogenic, sea salt and biogenic sources. Anthropogenic aerosols, with a winter-to-springtime maximum known as Arctic haze, contain particulate organic matter, nitrate, sulfate and black carbon which originate from North America and Eurasia (Sirois and Barrie, 1999; Quinn et al., 2002; Stone et al., 2014). Sea salt enters the atmosphere via mechanical processes such as sea spray and bubble bursting (Leck and Bigg, 2005a). The formation of breaking waves on the ocean surface (at wind speeds higher than $5 \mathrm{~m} \mathrm{~s}^{-1}$ ) leads to the entrainment of air as bubbles into surface ocean water. These bubbles rise to the surface due to their buoyancy and start to scavenge organic matter. They burst at the air-sea interface and release sea spray aerosol (SSA), which includes organic matter and inorganic sea salt (Quinn et al., 2015). Although, sea salt is generally found in coarse-mode particles, it is sometimes found in smaller sizes as well (Bates et al., 2006). Several mechanisms are responsible for the formation of SSA with different sizes. Small film drops are generated by the shattering of the film caps. Larger jet drops (with a size range of 1 to $25 \mu \mathrm{m}$ ) are formed by the collapse of the bubble cavity. Spume drops are torn from the crests of waves and enter the atmosphere directly at high wind speeds above $10 \mathrm{~m} \mathrm{~s}^{-1}$ (Lewis and Schwartz, 2004; Quinn et al., 2015).

The most important source of biogenic sulfate aerosols in the Arctic summer is the oxidation of dimethyl sulfide (DMS) (Norman et al., 1999). DMS is mostly produced by the breakdown of its algal precursor dimethylsulfonopropionate (DMSP) by phytoplankton and bacteria DMSP lyases and transported from the ocean to the atmosphere via turbulence and diffusion which depends on sea surface temperature, salinity and wind speed (Nightingale et al., 2000). Gaseous sulfur compounds from DMS oxidation are able to form new particles or condense onto preexisting aerosols in the atmosphere and thereby become large enough to act as cloud condensation nuclei (CCN) (Charlson et al., 1987). However, there are crucial uncertainties in the details of the potential impact of DMS on climate on a global scale (Quinn and Bates, 2011).

The formation of new particles and CCN is particularly important during the summer when anthropogenic aerosols are scarce, scavenging is efficient and sea-atmosphere gas exchange produces considerable DMS in the Arctic (Gabric et al., 2005; Elliott et al., 2012; Li and Barrie, 1993; Leaitch et al., 2013). Some studies have suggested an increase in biological activity, DMS production and emission with an increase in temperature and a decrease in sea-ice cover during summer (Sharma et al., 2012; Levasseur, 2013). However, modeling results from Browse et al. (2014) suggest that increased DMS emissions during summertime will not cause a strong climate feedback due to the efficient removal processes for aerosol particles. Such results are highly dependent on aerosol size distributions, which are relatively unconstrained particularly with respect to DMS oxidation (Bigg and Leck, 2001; Matrai et al., 2008; Quinn et al., 2009; Leaitch et al., 2013).

Tracers, such as DMS and methanesulfonate (MSA) for biogenic activities (Savoie et al., 2002), have been used in some studies to indicate different sources for sulfate. Other studies have assumed that non-sea-salt sulfur originates from biogenic sources in clean areas with low anthropogenic sulfur emissions (Bates et al., 1992; Hewitt and Davison, 1997). These methods may overestimate the role of biogenic sources if anthropogenic sulfate is present. The isotopic differences of various sources present a way to determine the oceanic DMS contribution to aerosol growth (Norman et al., 1999, 2004; Seguin et al., 2010, 2011; Rempillo et al., 2011). Sizesegregated aerosols were collected in July 2014 during an extended transect going from the strait of Belle Isle to Lancaster Sound in the Canadian Arctic, permitting comparison with measurements from other seasons. Sulfate aerosols have been apportioned into biogenic, anthropogenic and sea salt sulfate using sulfur isotopes, to find the contribution of each source in aerosol formation and growth.

\section{Field description and methods}

Particles were collected on board the Canadian Coast Guard Ship (CCGS) Amundsen in the Arctic during July 2014 as part of the NETCARE (Network on Climate and Aerosols: Addressing Key Uncertainties in Remote Canadian Environments) project. The route of this expedition, which took place from 8 to 24 July 2014, and sampling intervals are shown in Fig. 1 .

Wind speed and sea surface and air temperatures were documented every minute and averaged over 10 min using the Automatic Voluntary Observing Ships System (AVOS) system available onboard the Amundsen at $\sim 23 \mathrm{~m}$ above the sea surface. In addition, a version of the Lagrangian particle model, FLEXPART-WRF (FLEXible PARTicle dispersion model, Weather Research and Forecasting; Brioude et al., 2013), was used to estimate potential emission sensitivities. More details and figures of FLEXPART-WRF are published in other studies from the same campaign (NETCARE 2014; e.g., Mungall et al., 2015; Wentworth et al., 2016).

A high-volume sampler was used to collect aerosol samples at a calibrated flow rate of $1.08 \pm 0.05 \mathrm{~m}^{3} \mathrm{~min}^{-1}$. This high-volume sampler was placed facing the bow above the bridge of the ship, around $30 \mathrm{~m}$ above the sea surface. It was fitted with a cascade impactor to collect size-fractionated particles on quartz filters as well as $\mathrm{SO}_{2}$. The $\mathrm{SO}_{2}$ was trapped on a cellulose filter pretreated with potassium carbonate $\left(\mathrm{K}_{2} \mathrm{CO}_{3}\right)$ and a glycerol solution (Saltzman et al., 1983; Norman et al., 2004; Seguin et al., 2010). The sampling interval was 2 days, starting from 10:00 UTC. The high-volume sampler was turned off manually to avoid contamination when the ship emissions toward the sampler were 


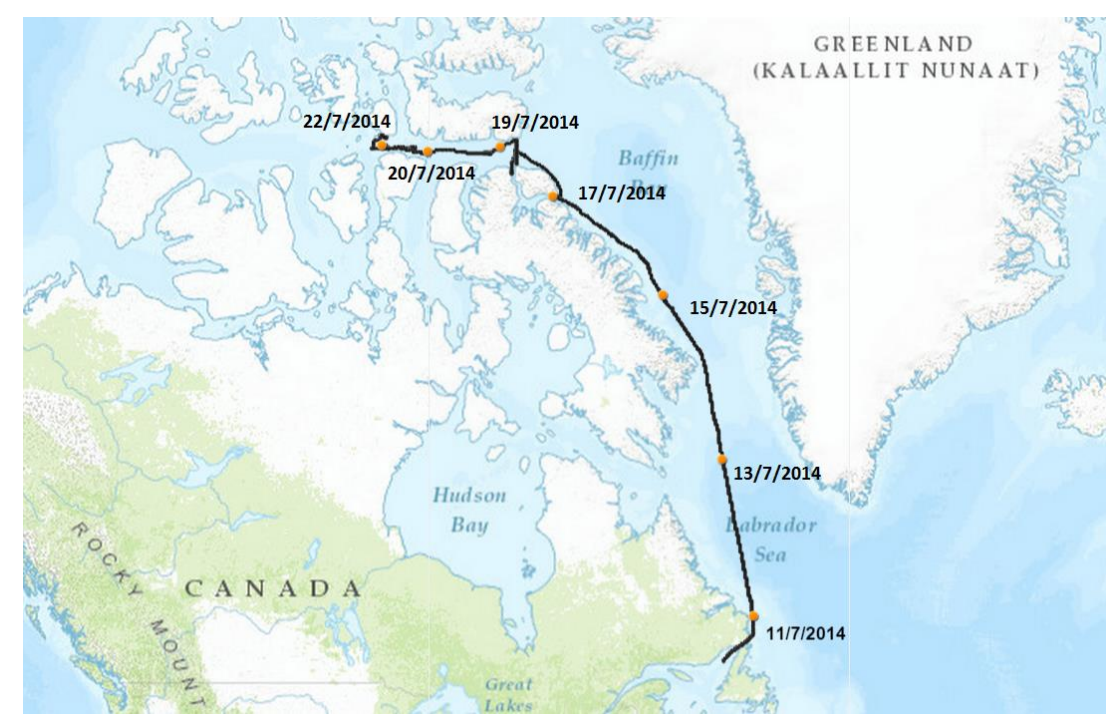

Figure 1. The route of CCGS Amundsen from 8 to 24 July 2014. Circles indicate sampling intervals for the high-volume sampler from 9 to 22 July $(9-11,11-13,13-15,15-17,17-19,20-22$ July). The high-volume sampler was off because of stormy weather from 10:00 on 19 July to $10: 00$ on 20 July.

observed or at times when the ship was stationary. Periods greater than $30 \mathrm{~min}$ are reported in Table 1. Figure 1 shows sampling intervals: the high-volume sampler was off because of stormy weather from 10:00 on 19 July to 10:00 on 20 July. The particle size was cut off at a flow rate of $1.13 \mathrm{~m}^{3} \mathrm{~min}^{-1}$, and standard temperature and pressure $\left(25^{\circ} \mathrm{C}\right.$ and $\left.1 \mathrm{~atm}\right)$ for spherical particles is at $50 \%$ collection efficiency, and the six ranges of particle aerodynamic diameter of the cascade impactor are as follows: A $(>7.2 \mu \mathrm{m}), \mathrm{B}(3.0-7.2 \mu \mathrm{m})$, $\mathrm{C}(1.5-3.0 \mu \mathrm{m}), \mathrm{D}(0.95-1.5 \mu \mathrm{m}), \mathrm{E}(0.49-0.95 \mu \mathrm{m})$ and $\mathrm{F}$ $(<0.49 \mu \mathrm{m})$. Temperature and pressure effects are negligible; however, the lower flow rate increases the cut off diameter slightly for each size range (Tisch Environmental, Inc., 2004). TOTAL sulfate refers to the sum of sulfate in each of the size fractions. Field blanks were collected on two separate occasions and loaded and unloaded with the same method as used to process the samples except that the highvolume sampler was turned off to assess whether and how much contamination occurred from procedural handling and analyses. Filters were stored in sealed ziplock bags at $<4^{\circ} \mathrm{C}$ before analysis in the lab.

A LI-COR $7000 \mathrm{CO}_{2} / \mathrm{H}_{2} \mathrm{O}$ Analyzer, with an inlet near the location of the high-volume sampler $(\sim 3 \mathrm{~m})$ and at the same height was used to measure the atmospheric $\mathrm{CO}_{2}$ mixing ratios. The objective of the $\mathrm{CO}_{2}$ measurement was to determine the influence of smoke stack emissions from the ship for quality assurance-quality control (QA/QC) of aerosol samples. The $\mathrm{CO}_{2}$ concentrations are shown in Fig. 2a. There were two periods when $\mathrm{CO}_{2}$ measurements were not saved due to a computer malfunction: 10:30 on 10 July to 09:00 on 11 July and 14:00 on 15 July to 10:35 on 17 July. The observation shows a relatively constant $\mathrm{CO}_{2}$ mixing ratio with
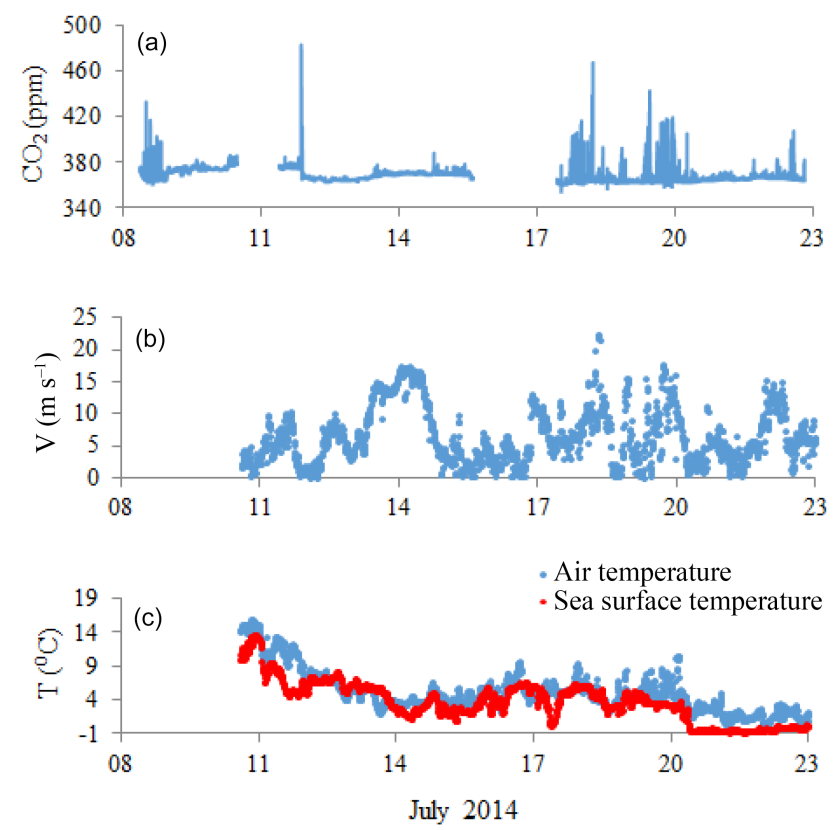

Figure 2. Panel (a): $\mathrm{CO}_{2}$ mixing ratio (ppm); panel (b): wind speed $\left(\mathrm{m} \mathrm{s}^{-1}\right)$; panel $(\mathbf{c})$ : sea surface and air temperatures $\left({ }^{\circ} \mathrm{C}\right) . \mathrm{CO}_{2}$ measurements were not reported from 10:30 on 10 July to 09:00 on 11 July and 14:00 on 15 July to 10:35 on 17 July. Wind speed and temperatures were not recorded before 11 July.

some peaks, indicating relatively little smoke stack contamination.

Once back in the laboratory, sulfate extracted from filter extracts was analyzed for sulfate isotopes and concentration. Filter papers were shredded in distilled deionized water and 
Table 1. Periods greater than $30 \mathrm{~min}$ when the high-volume sampler was off to avoid contamination from ship emissions. The sampling interval was 2 days, starting from 10:00.

\begin{tabular}{|c|c|c|}
\hline $\begin{array}{l}\text { Sampling interval } \\
\text { (July 2014) }\end{array}$ & $\begin{array}{l}\text { Turn off-on time (UTC) } \\
\text { of the high-volume sampler }\end{array}$ & $\begin{array}{l}\text { Reason for turning off } \\
\text { the high-volume sampler }\end{array}$ \\
\hline $9-11$ & 10 July: $12: 40-13: 10$ & Ship emissions toward the sampler \\
\hline $11-13$ & 11 July: 11:20-13:30 & Exchange of the sampler exhaust \\
\hline $13-15$ & 15 July: 06:30-08:00 & The ship was stationary \\
\hline $15-17$ & 17 July: 08:00-10:00 & The ship was stationary \\
\hline $17-19$ & 18 July: 22:00-07:00* & The ship was stationary \\
\hline $2-22$ & 21 July: 15:30-16:10 & Ship emissions toward the sampler \\
\hline
\end{tabular}

* 07:00 on the following day 19 July.

sonicated for $30 \mathrm{~min}$. Then, filter paper fibers were removed by $0.45 \mathrm{~mm}$ Millipore filtration, and a portion of the filtrate samples $(2 \times 10 \mathrm{~mL})$ was used for ion concentration measurements. Remaining filtrate was treated with $5 \mathrm{~mL}$ of $10 \%$ $\mathrm{BaCl}_{2}$ and $1 \mathrm{~mL} \mathrm{HCl}$ to precipitate $\mathrm{BaSO}_{4}$. In addition to $\mathrm{BaCl}_{2}$ and $\mathrm{HCl}, 2 \mathrm{~mL}$ of $30 \%$ hydrogen peroxide was added to $\mathrm{SO}_{2}$ filter solutions to oxidize the $\mathrm{SO}_{2}$ to sulfate. After extraction, $\mathrm{BaSO}_{4}$ was dried and samples were packed into tin cups and analyzed with a PRISM II continuous flow isotope ratio mass spectrometer (CF-IRMS) to obtain $\delta^{34} \mathrm{~S}$ values in parts per thousand $(\% o$ ) (relative to VCDT, Vienna Cañon Diablo Triolite) (Seguin et al., 2010). $\delta^{34} \mathrm{~S}$ for sulfur isotopes is shown by the abundance ratio of the two principal sulfur isotopes $\left({ }^{34} \mathrm{~S} /{ }^{32} \mathrm{~S}\right)$ (Krouse et al., 1991).

$$
\begin{aligned}
\delta^{34} \mathrm{~S}(\% \circ) & =\left\{\left({ }^{34} \mathrm{~S} /{ }^{32} \mathrm{~S}\right) \text { sample } /\right. \\
& \left.\left({ }^{34} \mathrm{~S} /{ }^{32} \mathrm{~S}\right) \text { standard }-1\right\} \times 1000
\end{aligned}
$$

The uncertainty for $\delta^{34} \mathrm{~S}$ values $( \pm 0.3 \%$ ) was determined by the standard deviation of the $\delta^{34} \mathrm{~S}$ values of a suite of internal standards bracketing the $\delta^{34} \mathrm{~S}$ values of the samples.

Concentrations of cations $\left(\mathrm{Ca}^{2+}, \mathrm{K}^{+}, \mathrm{Na}^{+}, \mathrm{Mg}^{2+}\right)$ and anions $\left(\mathrm{Cl}^{-}, \mathrm{SO}_{4}^{2-}, \mathrm{PO}_{4}^{3-}, \mathrm{NO}_{3}^{-}\right)$were obtained by ion chromatography with a detection limit of $0.1 \mathrm{mg} \mathrm{L}^{-1}$. No peaks were detected for sulfate in the blank filters, and the average concentration of $\mathrm{Na}^{+}$in the blank filters was $1.2 \mathrm{mg} \mathrm{L}^{-1}$ after extraction (which is around 5 and $20 \%$ of the maximum and minimum of the $\mathrm{Na}^{+}$concentration in filter $\mathrm{A}$ with the most sea salt).

Three different sources - anthropogenic, biogenic and sea salt - was considered for sulfur aerosols and the fraction of each source was obtained using

$$
\begin{aligned}
& {\left[\mathrm{SO}_{4}^{2-}\right]_{\text {total }}=\left[\mathrm{SO}_{4}^{2-}\right]_{\text {bio }}+\left[\mathrm{SO}_{4}^{2-}\right]_{\text {anthro }}+\left[\mathrm{SO}_{4}^{2-}\right]_{\mathrm{SS}}} \\
& {\left[\mathrm{SO}_{4}^{2-}\right]_{\text {total }} \delta^{34} \mathrm{~S}_{\text {total }}=\left[\mathrm{SO}_{4}^{2-}\right]_{\text {bio }} \delta^{34} \mathrm{~S}_{\text {bio }}} \\
& \quad+\left[\mathrm{SO}_{4}^{2-}\right]_{\text {anthro }} \delta^{34} \mathrm{~S}_{\text {anthro }}+\left[\mathrm{SO}_{4}^{2-}\right]_{\mathrm{SS}} \delta^{34} \mathrm{~S}_{\mathrm{SS}} .
\end{aligned}
$$

Also, $\delta^{34} \mathrm{~S}_{\mathrm{NSS}}$ was determined using the expression for twosource mixing:

$[\mathrm{NSS}] \delta^{34} \mathrm{~S}_{\mathrm{NSS}}=[$ measured $] \delta^{34} \mathrm{~S}_{\text {measured }}-[\mathrm{SS}] \delta^{34} \mathrm{~S}_{\mathrm{SS}}$, where SS and NSS refer to sea salt and non-sea-salt sulfate, respectively, and quantities in brackets, $[X]$, indicate concentrations.

The amount of sea salt sulfate in sea water was calculated by $\mathrm{SO}_{4}^{2-}$ and $\mathrm{Na}^{+}$mass ratios:

$\left[\mathrm{SO}_{4}^{2-}\right]_{\mathrm{SS}}=0.252\left[\mathrm{Na}^{+}\right]$.

Sulfur isotope apportionment in the Arctic assumes a $\delta^{34} \mathrm{~S}$ value of $+21 \% \circ \pm 0.1$ (Rees et al., 1978), $+18.6 \%$ \pm 0.9 (Sanusi et al., 2006; Patris et al., 2002) and $+3 \%$ \pm 3 (Li and Barrie, 1993; Nriagu and Coker, 1978; Norman et al., 1999) for sea salt, biogenic and anthropogenic $\delta^{34} S$ values, respectively. These values were used to find sea salt, biogenic and anthropogenic fractions in this study. The partial derivative rule for error propagation and standard deviation were considered for uncertainties.

\section{Results}

\subsection{The meteorological measurements}

Interaction of wind at the ocean's surface may lead to the formation of primary coarse-mode sea salt particles. DMS oxidation pathways, the formation of biogenic $\mathrm{SO}_{2}$ and the production of new particles are influenced by wind speed and temperature. Wind speed and sea and air temperatures from the Amundsen's AVOS system are shown in Fig. 2b and c.

\subsection{Sulfate aerosols}

Total, sea salt and non-sea-salt sulfate concentrations and their standard deviations for the entire sampling program for different size fractions are summarized in Table 2.

Similar average sulfate concentrations were found for aerosols in $A_{>} 7.2 \mu \mathrm{m}\left(113 \mathrm{ng} \mathrm{m}^{-3}\right), B_{3.0-7.2 \mu \mathrm{m}}\left(100 \mathrm{ng} \mathrm{m}^{-3}\right)$ and $D_{0.95-1.5 \mu \mathrm{m}}\left(110 \mathrm{ng} \mathrm{m}^{-3}\right)$ size fractions. An average sulfate concentration of $34 \mathrm{ng} \mathrm{m}^{-3}$ was found for the $C_{1.5-3.0 \mu \mathrm{m}}$ size aerosols. On the other hand, the $\mathrm{F}_{<0.49 \mu \mathrm{m}}$ filter (fine aerosol) has the highest average sulfate concentration 
Table 2. Average TOTAL, sea salt and non-sea-salt sulfate concentrations ( $\mathrm{ng} \mathrm{m}^{-3}$ ), sulfur isotopic values (\%o), and non-sea-salt fraction (\%) for size-segregated aerosol filters. Standard deviations are reported in parentheses.

\begin{tabular}{lrrrrr}
\hline $\begin{array}{l}\text { Filter size } \\
(\mu \mathrm{m})\end{array}$ & $\begin{array}{r}\text { Average sulfate } \\
\left(\mathrm{ng} \mathrm{m}^{-3}\right)\end{array}$ & $\begin{array}{r}\text { Average } \delta^{34} \mathrm{~S} \\
(\%)\end{array}$ & $\begin{array}{r}\text { SS sulfate } \\
\left(\mathrm{ng} \mathrm{m}^{-3}\right)\end{array}$ & $\begin{array}{r}\text { NSS sulfate } \\
\left(\mathrm{ng} \mathrm{m}^{-3}\right)\end{array}$ & $\begin{array}{r}\text { Fraction of NSS } \\
\text { sulfate }(\%)\end{array}$ \\
\hline $\mathrm{A}_{>} 7.20 \mu \mathrm{m}$ & $113(93)$ & $+18.9(1.1)$ & $99(85)$ & $14(13)$ & 12 \\
$\mathrm{~B}_{3.00-7.20 \mu \mathrm{m}}$ & $100(82)$ & $+18.2(1.2)$ & $86(75)$ & $14(8)$ & 14 \\
$\mathrm{C}_{1.50-3.00 \mu \mathrm{m}}$ & $34(20)$ & $+18.0(0.6)$ & $27(20)$ & $8(1)$ & 23 \\
$\mathrm{D}_{0.95-1.50 \mu \mathrm{m}}$ & $110(200)$ & $+16.0(2.3)$ & $55(93)$ & $55(110)$ & 50 \\
$\mathrm{E}_{0.49-0.95 \mu \mathrm{m}}$ & $71(130)$ & $+12.3(5.8)$ & $5(5)$ & $66(120)$ & 92 \\
$\mathrm{~F}_{<0.49 \mu \mathrm{m}}$ & $214(320)$ & $+14.0(1.5)$ & $6(6)$ & $208(320)$ & 97 \\
\hline
\end{tabular}

$\left(\sim 214 \mathrm{ng} \mathrm{m}^{-3}\right)$ and contains less than $3 \%$ sea salt sulfate $\left(6 \mathrm{ng} \mathrm{m}^{-3}\right)$.

\subsubsection{Sea salt sulfate}

Table 2 includes average sea salt sulfate concentrations for aerosols for different size fractions for this study. As expected, coarse-size filters $A_{>7.2 \mu m}$ and $B_{3.0-7.2}$ in this study contain more sea salt sulfate than smaller-diameter aerosols and the average sea salt sulfate is approximately 6 times higher than non-sea-salt sulfate. In contrast, smaller aerosols on the $\mathrm{D}_{0.95-1.5} \mu \mathrm{m}$ filter contain lower but significant amounts of sea salt sulfate $\left(\sim 55 \mathrm{ng} \mathrm{m}^{-3}\right)$. Although, on average, more than 75 percent of sulfate for the $\mathrm{C}_{1.5-3.0 \mu \mathrm{m}}$ filter is from sea salt, a considerable decrease in concentration is observed compared to $\mathrm{A}_{>7.2 \mu \mathrm{m}}, \mathrm{B}_{3.0-7.2 \mu \mathrm{m}}$ and $\mathrm{D}_{0.95-1.5 \mu \mathrm{m}}$ filters. Sea salt sulfate concentrations are low for aerosols collected on the $\mathrm{E}_{0.49-0.95 \mu \mathrm{m}}$ and $\mathrm{F}_{<0.49 \mu \mathrm{m}}$ filters ( $\sim 5$ to $\left.6 \mathrm{ng} \mathrm{m}^{-3}\right)$. The spatial variability of TOTAL sulfate and sea salt concentrations is shown in Fig. 3a.

\subsubsection{Non-sea-salt sulfate}

The average non-sea-salt sulfate concentrations for the entire study are reported in Table 2 (spatial variation in non-seasalt sulfate is shown in Fig. 3b). Results show approximately uniform TOTAL non-sea-salt sulfate concentrations (average $130 \pm 21 \mathrm{ng} \mathrm{m}^{-3}$; range from 102 to $152 \mathrm{ng} \mathrm{m}^{-3}$ ), except the first sample collected nearby the Gulf of St Lawrence (8 to 10 July) which contains the highest non-sea-salt sulfate concentration. The majority of sulfate for small aerosols in the $\mathrm{D}_{0.95-1.5 \mu \mathrm{m}}\left(\sim 55 \mathrm{ng} \mathrm{m}^{-3}, 50 \%\right), \mathrm{E}_{0.49-0.95 \mu \mathrm{m}}\left(\sim 66 \mathrm{ng} \mathrm{m}^{-3}\right.$, $93 \%)$ and $\mathrm{F}_{<0.49 \mu \mathrm{m}}\left(\sim 208 \mathrm{ng} \mathrm{m}^{-3}, 97 \%\right)$ fractions is from non-sea-salt sources.

\section{Discussion}

\subsection{Sea salt sulfate}

Sea salt concentrations are variable with season and depend on atmospheric stability (Lewis and Schwartz, 2004). Although wind is considered an important factor in the seaair exchange of sea salt, correlations in this study between wind speed and sea salt sulfate concentrations for coarse- and fine-mode aerosols were not significant $\left(R^{2} \cong 0.1\right)$, which is consistent with previous studies (Lewis and Schwartz, 2004; Rempillo et al., 2011; Seguin et al., 2011; Jaeglé et al., 2011).

\subsection{Non-sea-salt sulfate}

The spatial variation of non-sea-salt sulfate (anthropogenic plus biogenic aerosols) is shown in Fig. 3b. Results show approximately uniform non-sea-salt sulfate concentrations for samples in the Labrador Sea and further north $\left(130 \pm 21 \mathrm{ng} \mathrm{m}^{-3}\right)$. Sulfate concentrations, especially nonsea-salt sulfate, in this research were found to be higher than previous Arctic studies above the ocean during fall (20072008) (Rempillo et al., 2011) and at higher latitudes at Alert in summer (1993-1994) (Norman et al., 1999) and about the same as at Barrow, Alaska during July (1997-2008) (Quinn et al., 2009). One reason could be higher biological activity and biogenic aerosols from phytoplankton during summer, as addressed in the next section.

\subsection{Sulfur isotope apportionment}

Total $\delta^{34} \mathrm{~S}$ versus the percentage of sea salt sulfate of size-fractionated aerosols is shown in Fig. 4. The mixing lines for sea salt-biogenic sulfate (solid line) and sea saltanthropogenic sulfate (dashed line) are shown to demonstrate mixing for each pair of sources. Data from this study fall mainly within the mixing lines, which suggests that the assignment of the end-member $\delta^{34} \mathrm{~S}$ values is appropriate. However, it can also be seen that the data lie in two groups. One cluster has a high percentage of sea salt sulfate ( $>40$ to $>95 \%$ ) and the second has a very low percentage of $(<10 \%)$ sea salt sulfate. There is a high contribution of 

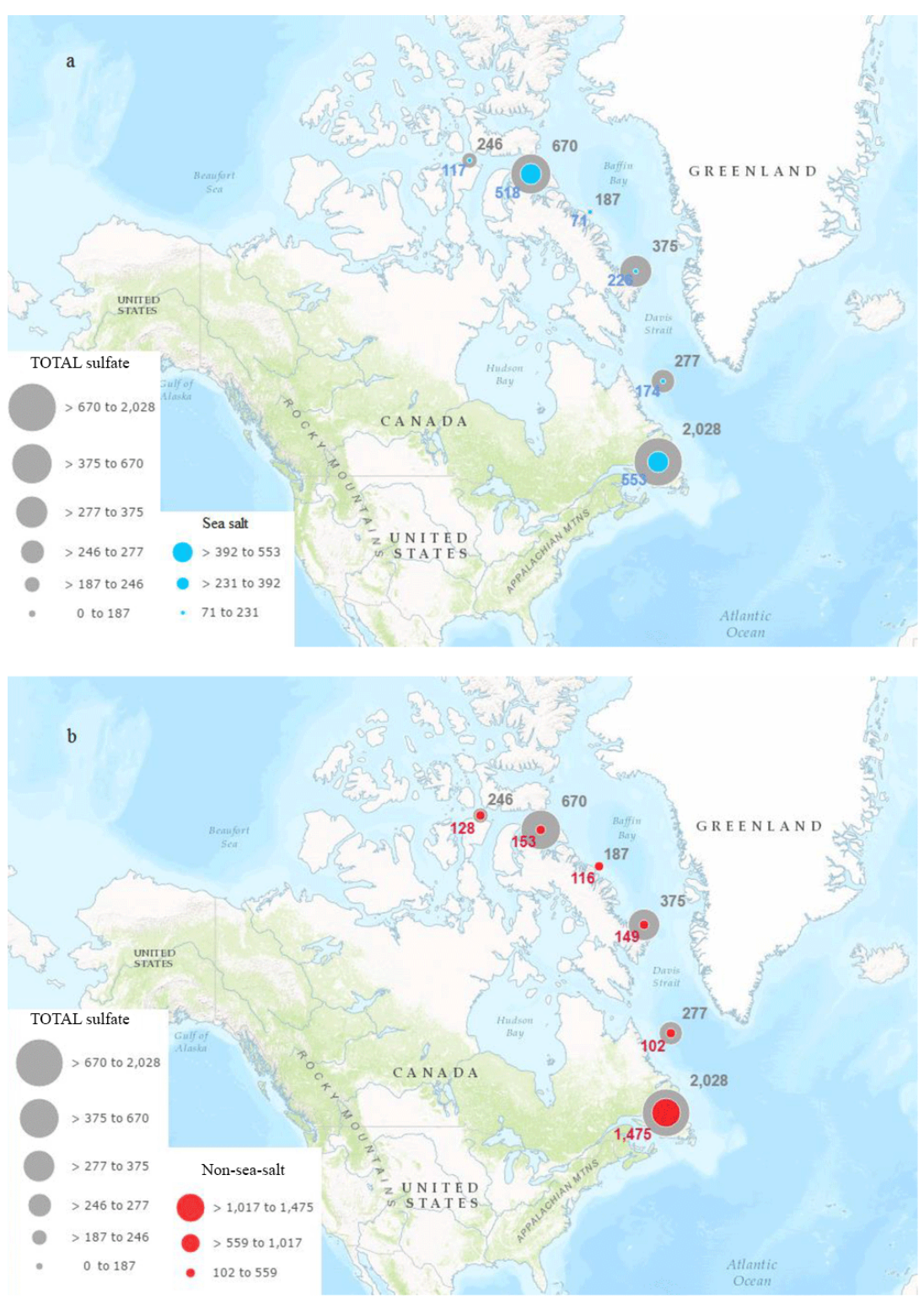

Figure 3. TOTAL sulfate, sea salt (a) and non-sea-salt (b) sulfate concentrations $\left(\mathrm{ng} \mathrm{m}^{-3}\right.$ ) of aerosols on $\mathrm{A}_{>} 7.2 \mu \mathrm{m}-\mathrm{F}_{<0} 0.49 \mu \mathrm{m}$ filters. Numbers in the figure show TOTAL, sea salt and non-sea-salt sulfate concentrations $\left(\mathrm{ng} \mathrm{m}^{-3}\right)$ in gray, blue and red colors, respectively.

sea salt sulfate for aerosols on filters $\mathrm{A}_{>7.2 \mu \mathrm{m}}$ and $\mathrm{B}_{3.0-7.2 \text {, }}$ and this decreases for smaller-size aerosols. Sulfate aerosols on the $\mathrm{A}_{>7.2 \mu \mathrm{m}}$ filter lie along the sea salt-anthropogenic mixing line and are consistent with sea spray and a small contribution from the ship's stack emission. Aerosols on the $\mathrm{B}_{3.0-7.2 \mu \mathrm{m}}, \mathrm{C}_{1.5-3.0 \mu \mathrm{m}}$ and $\mathrm{D}_{0.95-1.5 \mu \mathrm{m}}$ filters and most of the $\mathrm{E}_{0.49-0.95 \mu \mathrm{m}}$ filters lie between the upper and lower mixing line near the right-hand side of the Fig. 4. This indicates that sulfate is dominated by sea salt for these samples, and the remainder is a mixture of biogenic and anthropogenic sulfate. The $\delta^{34} \mathrm{~S}$ value for aerosols $<0.49 \mu \mathrm{m}\left(\mathrm{F}_{<0.49 \mu \mathrm{m}}\right.$ filter $)$ is more variable, it indicates that very little sea salt sulfate is present, and the majority of the sulfate is derived from a mixture of biogenic and anthropogenic sulfate. Norman et al. (1999) showed that most data from Alert during spring, fall and winter lie between 0 and $+7 \%$, which demonstrates a combination of anthropogenic and sea salt sulfate aerosols. Also, their data show an increase in $\delta^{34} \mathrm{~S}$ values during summer (between +7 and $+15 \%$ ) and confirm the importance of biogenic sulfate. The $\delta^{34} \mathrm{~S}$ data for non-seasalt sulfate from Rempillo et al. (2011) illustrate the dominance of anthropogenic sources (more than $70 \%$ ) during fall 2007 and 2008. In addition, Rempillo et al. (2011) introduced a new sulfate source, the Smoking Hills $\left(\delta^{34} \mathrm{~S}=-30 \%\right.$ o). This new source altered background $\delta^{34} \mathrm{~S}$ to $-30 \%$ near the Smoking Hills on Cape Bathurst, Northwest Territories 


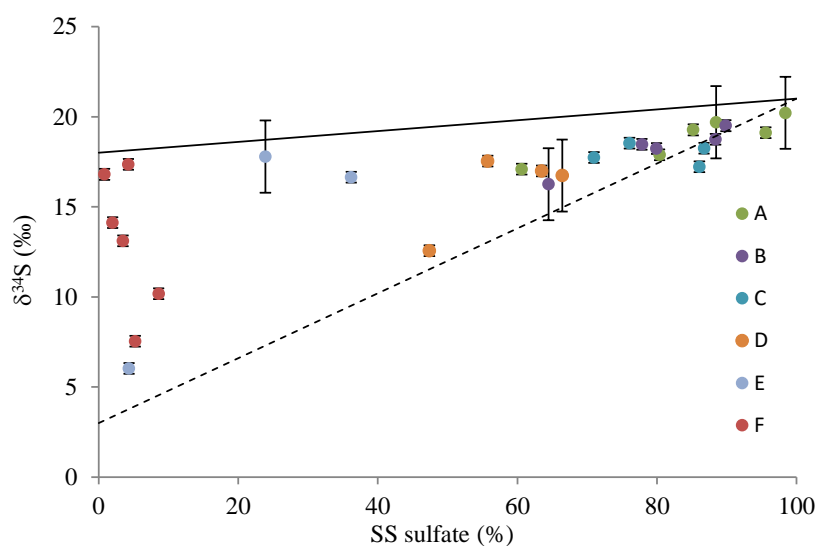

Figure 4. Total $\delta^{34} \mathrm{~S}$ versus the percentage of sea salt sulfate of size-fractionated aerosols. The mixing lines show sea salt-biogenic sulfate (solid line) and sea salt-anthropogenic sulfate (dashed line) contributions. The standard deviations of each run were taken as the uncertainty for $\delta^{34} \mathrm{~S}$ values.

(Fig. 1) and $\delta^{34} \mathrm{~S}=-5 \%$ o further away. There is no evidence from the isotope data for a significant contribution of sulfate from the Smoking Hills in this study; however, results from FLEXPART-WRF modeling show that several potential emissions originated in or passed near the Smoking Hills (Fig. 5).

\subsection{Anthropogenic and biogenic sulfate}

The concentration of sulfate for aerosol samples derived from apportionment calculations for non-sea-salt sulfate, anthropogenic and biogenic sources is shown in Fig. 6 . Results show an approximately uniform concentration $\left(130 \pm 21 \mathrm{ng} \mathrm{m}^{-3}\right)$ for sulfate aerosols in the Arctic region, aside from the Gulf of the St Lawrence, which has around 4 times higher concentrations (Fig. 6a). In addition, the highest concentration for both anthropogenic and biogenic sulfate was found in the $\mathrm{F}_{<0.49 \mu \mathrm{m}}$ filter in the Arctic region.

Two possible sources for anthropogenic sulfate are ship emissions and long-range transport (LRT). In the Arctic $\mathrm{CO}_{2}$ above background is likely from ship emissions. The question is what is the appropriate background $\mathrm{CO}_{2}$ mixing ratio? Analyses were performed assuming three different levels for background $\mathrm{CO}_{2}(380,385,400 \mathrm{ppm})$. The result of these analyses indicates that $\mathrm{CO}_{2}$ mixing ratios (Fig. 2a) reached 380, 385 and $400 \mathrm{ppm}$ for less than 1.5, 0.5 and $0.1 \%$ of sampling time, respectively, and were relatively uniform in comparison with similar measurements by Rempillo et al. (2011), which reached more than $2000 \mathrm{ppm}$ when stack emissions impacted the samples (on average, $5 \%$ of the sampling time; O. Rempillo, personal communication, June 2015). Therefore, the direct impact of ship stack emissions on most aerosol samples in this study collected is expected to be small. This was confirmed by nearly white filter samples after collection for all size fractions during this study compared to filters which appeared gray or black when contaminated by ship stack sulfate in the Surface Ocean Lower Atmosphere Study (SOLAS) study from 2007 to 2008 (O. Rempillo, personal communication, June 2015; Rempillo et al., 2011). Furthermore, weak correlations were observed between anthropogenic sulfate and $\mathrm{CO}_{2}$ for the $\mathrm{A}_{>7.2 \mu \mathrm{m}}$, $\mathrm{B}_{3.0-7.2 \mu \mathrm{m}}, \mathrm{D}_{0.95-1.5 \mu \mathrm{m}}, \mathrm{E}_{0.49-0.95 \mu \mathrm{m}}$ and $\mathrm{F}_{<0.49 \mu \mathrm{m}}$ samples, suggesting that some portion of the anthropogenic sulfate was locally derived from the ship's emissions. However, the correlations were poor, so $\mathrm{CO}_{2}$ is not considered an adequate tracer to distinguish local sulfate from LRT.

Long-range transport of $\mathrm{SO}_{2}$ and particles is a second potential mechanism affecting the concentration of anthropogenic sulfate during this study. The lifetime of $\mathrm{SO}_{2}$ in the Arctic is more than 1 week (Thornton et al., 1989), and this means that $\mathrm{SO}_{2}$ potentially acts as a reservoir from which new anthropogenic aerosols could form. Long-range transport of anthropogenic sulfur dominates in the Arctic winter and early spring because of the stable atmosphere and weak removal of particles, and concentrations significantly decrease during summer because of a lower number of sources within the polar front and stronger scavenging (Quinn et al., 2002; Stone et al., 2014). The backward configuration modeling of FLEXPART-WRF shows that potential emissions originated from the east for the first 2 days (12 and 13 July), and expanded to cover a broader region after that (Fig. 5 shows some examples of backward configuration results of FLEXPART-WRF). The Hudson Bay area is an important source of DMS (Richards et al., 1994), and air parcels originating from Hudson Bay may contain more biogenic $\mathrm{SO}_{2}$ and sulfate. On the other hand, air parcels originating from the south (North America) may contain more pollution from LRT.

Figure $6 \mathrm{~b}$ shows the time series of anthropogenic sulfate concentrations for size-segregated aerosols. The size fraction of aerosols is different for two distinct anthropogenic sources: long-range transport and ship emissions. The contribution of anthropogenic sulfate from long-range transport is highest for the first sample collected in the Gulf of St Lawrence and is pronounced in the $\mathrm{E}_{0.49-0.95 \mu \mathrm{m}}$ and $F_{<0.49 \mu \mathrm{m}}$ filters. On the other hand, the anthropogenic aerosol sulfate concentrations on filters $\mathrm{A}_{>7.2 \mu \mathrm{m}}, \mathrm{B}_{3.0-7.2 \mu \mathrm{m}}$ and $\mathrm{C}_{1.5-3.0 \mu \mathrm{m}}$ were highest for samples collected from 17 to 19 July, which suggests more sulfate from the ship's emissions. Although the high-volume sampler was turned off when the ship was stationary on each of these days, some anthropogenic aerosols from ship emissions may have influenced the results for aerosol sulfate in that time period (17 to 19 July).

A considerable amount of the sulfate concentration, ranging from 18 to $625 \mathrm{ng} \mathrm{m}^{-3}$ for $\mathrm{F}_{<0.49 \mu \mathrm{m}}$ filters, is from biogenic sources. These values are higher than previously measured in the Arctic. For example, the average biogenic TOTAL sulfate concentration at Alert was around $30 \mathrm{ngS} \mathrm{m}^{-3}$ during July (Norman et al., 1999). Also, Rem- 

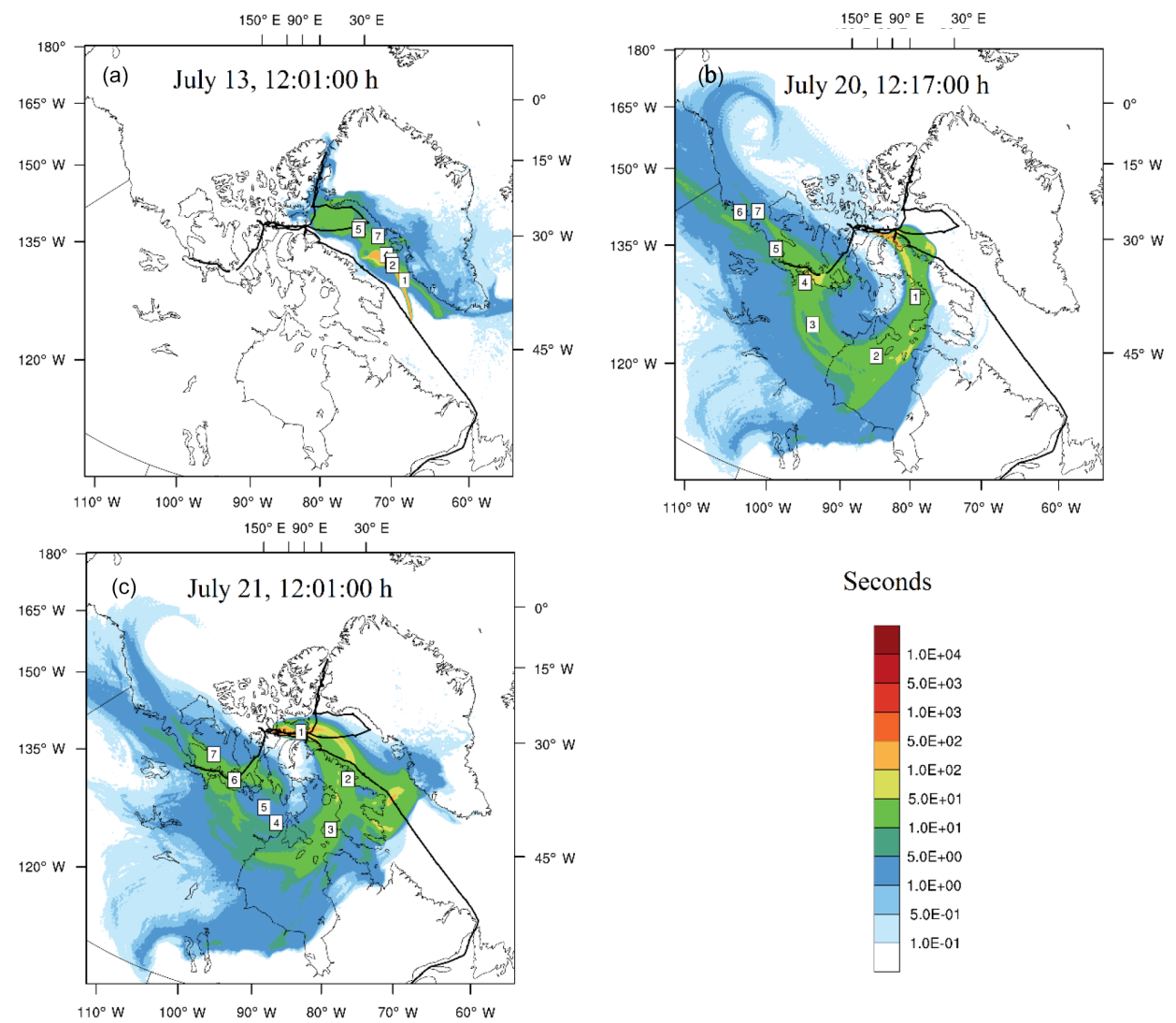

Seconds

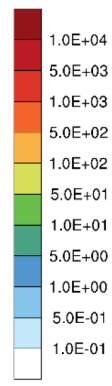

Figure 5. FLEXPART-WRF backward configuration of potential emission sensitivity plots for (a) 13 July (12:01:00), (b) 20 July (12:17:00) and (c) 21 July (12:01:00). The black line shows the ship track (note that these panels include the ship track after 23 July 2014 when highvolume sampling was not performed). The air mass residence time (seconds) before arriving at the ship location is shown with different colors. Numbers on the panels show the approximate lifetime and the center of the plume locations.

Table 3. Biogenic fraction of non-sea-salt sulfate (\%) for each size range of filter. There was not enough sample for isotope analysis for some periods.

\begin{tabular}{lrrrrrr}
\hline Filter size $(\mu \mathrm{m}) /$ sampling intervals & $9-11$ & $11-13$ & $13-15$ & $15-17$ & $17-19$ & $20-22$ \\
\hline $\mathrm{A}_{>} 7.20 \mu \mathrm{m}$ & 42 & 44 & - & 54 & - & 14 \\
$\mathrm{~B}_{3.00-7.20 \mu \mathrm{m}}$ & 28 & 22 & - & 31 & - & 44 \\
$\mathrm{C}_{1.50-3.00 \mu \mathrm{m}}$ & - & 51 & 47 & - & - & 45 \\
$\mathrm{D}_{0.95-1.50 \mu \mathrm{m}}$ & 13 & 67 & 47 & - & - & 66 \\
$\mathrm{E}_{0.49-0.95 \mu \mathrm{m}}$ & 15 & 74 & 85 & - & - & 30 \\
$\mathrm{~F}_{<0.49 \mu \mathrm{m}}$ & 73 & 95 & 92 & 25 & 41 & 65 \\
\hline
\end{tabular}

pillo et al. (2011) reported low biogenic sulfate concentrations with a maximum and median equal to 115.2 and $0 \mathrm{ng} \mathrm{m}^{-3}$, respectively, above the Arctic Ocean in the Canadian Arctic Archipelago during fall 2007 and 2008.

Figure $6 \mathrm{~b}$ and $\mathrm{c}$ show that filter $\mathrm{F}_{<0.49 \mu \mathrm{m}}$ contains the highest biogenic and anthropogenic sulfate concentrations for all samples (except anthropogenic sulfate for 11-13 July). The biogenic fraction of non-sea-salt sulfate for each size range is reported in Table 3: high fractions of sulfate on fil-

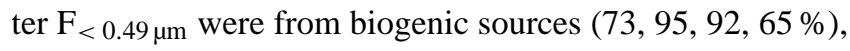

except for two samples collected on July 15-17 (25\%) and 17-19 (41\%) (see Sect. 4.5).

\subsection{Aerosol growth}

The oxidation of $\mathrm{SO}_{2}$ occurs in the gas phase, the aqueous phase and also on the surface of particles. The rate of this oxidation depends on factors such as the presence of the aqueous phase in the form of clouds and fogs, the concentration of oxidants such as $\mathrm{H}_{2} \mathrm{O}_{2}$ and $\mathrm{O}_{3}$, cloud $\mathrm{pH}$, and sunlight in- 

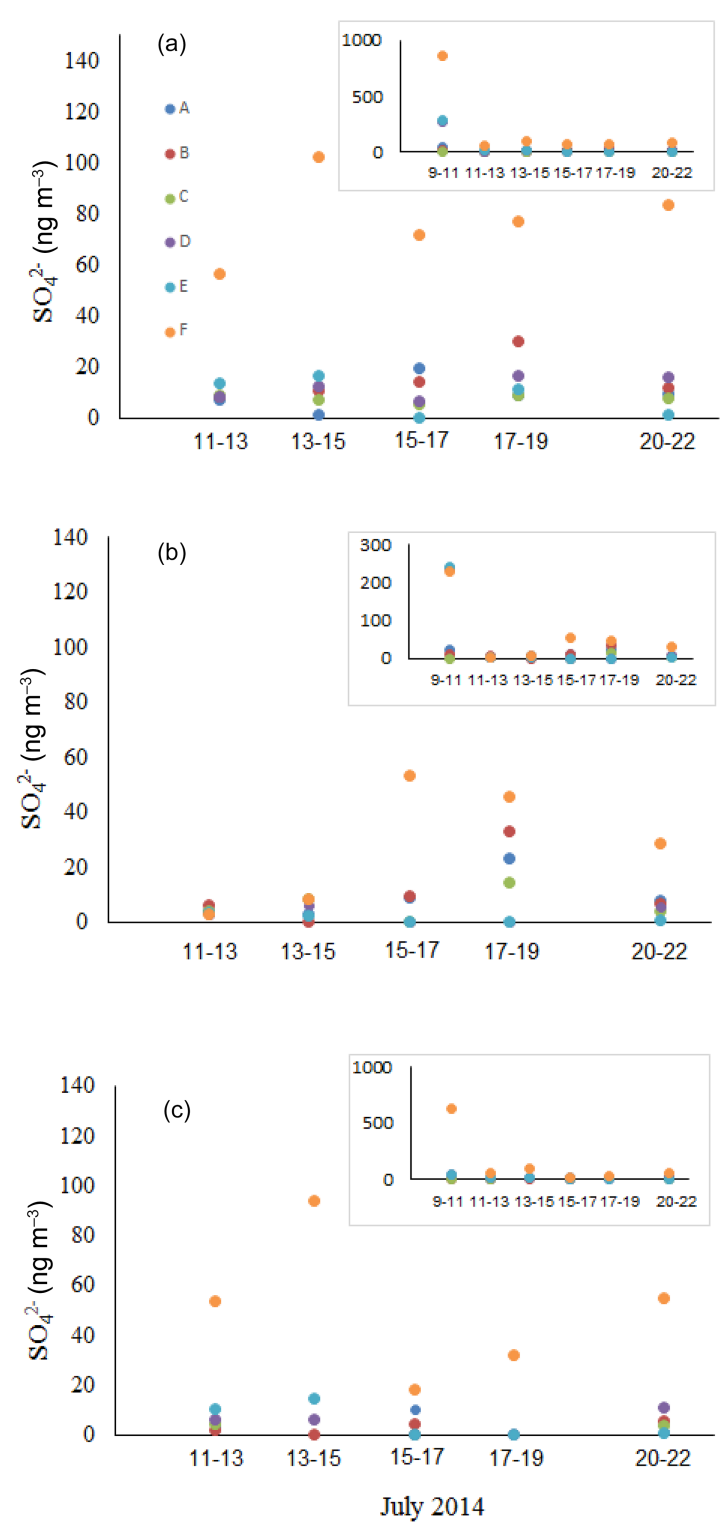

Figure 6. Non-sea salt (a), anthropogenic (b) and biogenic (c) sulfate concentrations for size-segregated aerosols in the Arctic and subarctic. Strictly speaking, Arctic samples include those collected after 13 July. Inserts contain the first sampling period (9-11 July) in the Gulf of St Lawrence.

tensity. The $\delta^{34} \mathrm{~S}$ value of aerosols reflects the proportion of $\delta^{34} \mathrm{~S}$ values for preexisting aerosols and $\mathrm{SO}_{2}$ by the oxidation of local $\mathrm{SO}_{2}$ on the surface of, or within, preexisting aerosols (Seguin et al., 2011). Although the $\delta^{34} \mathrm{~S}$ value for preexisting aerosols is not clear, it is reasonable to assume that particles with different sizes and the same $\delta^{34} \mathrm{~S}$ value originate from the same source (Seguin et al., 2011). However, sulfur isotope fractionation can confound apportionment. Harris et al. (2013) reported sulfur isotope fractionation due to $\mathrm{SO}_{2}$ oxidation, which depends on temperature and oxidation pathways. By solving isotope fractionation equations (Harris

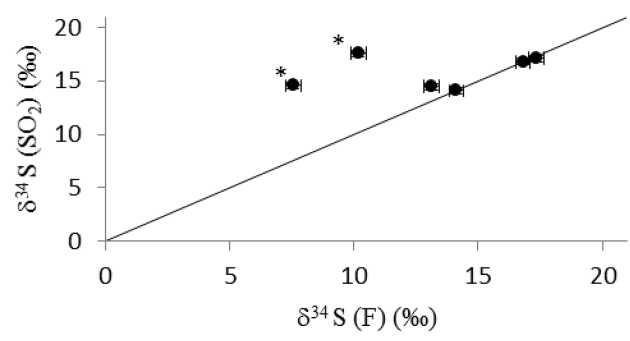

Figure 7. The isotope ratio $\left(\delta^{34} \mathrm{~S}\right.$ value $)$ for $\mathrm{F}_{<0.49 \mu \mathrm{m}}$ and $\mathrm{SO}_{2}$ filters along with the $1: 1$ line. Two samples with different $\delta^{34} \mathrm{~S}$ values for $\mathrm{SO}_{2}$ and $\mathrm{F}_{<0.49 \mu \mathrm{m}}$ filter sulfate are shown with asterisks.

et al., 2013) for the average temperature during sampling for this study $\left(\sim 5^{\circ} \mathrm{C}\right), \delta^{34} \mathrm{~S}$ values of sulfate are $10.6 \pm 0.7 \%$, $16.1 \pm 0.1 \%$ and $-6.22 \pm 0.02 \%$ o for homogeneous, heterogeneous and transition metal ion (TMI) oxidation, respectively. However, a comparison of the $\delta^{34} \mathrm{~S}$ values for $\mathrm{SO}_{2}$ and the $\mathrm{F}_{<0.49 \mu \mathrm{m}}$ filter (or any other size fractions) does not support consistent isotope fractionation during $\mathrm{SO}_{2}$ oxidation for samples collected during this campaign.

The isotope ratios $\left(\delta^{34} \mathrm{~S}\right.$ value) for $\mathrm{F}_{<0.49 \mu \mathrm{m}}$ and $\mathrm{SO}_{2}$ filters are shown in Fig. 7 along with the $1: 1$ line. Four of six samples lay close to the $1: 1$ line, which suggests that they have the same source or mixture of sources (and the same isotope ratio value). However, there are two samples, collected on 15-17 and 17-19 July, with different $\delta^{34} S$ values for $\mathrm{SO}_{2}$ and $\mathrm{F}_{<0.49 \mu \mathrm{m}}$ filter sulfate, which are shown with an asterisk on Fig. 7. The anthropogenic fraction of sulfate for the $\mathrm{F}_{<0.49 \mu \mathrm{m}}$ filter for these two sampling periods is relatively high. Although the anthropogenic fraction of sulfate in $\mathrm{F}_{<0.49 \mu \mathrm{m}}$ filters for these two sampling periods was higher than the remainder of samples (refer to Sect. 4.4), $\mathrm{SO}_{2}$ was predominantly biogenic (more than $80 \%$ ).

Conditions for aerosol nucleation based on biogenic $\mathrm{SO}_{2}$ concentrations were evaluated by Rempillo et al. (2011). They showed that the threshold value for biogenic $\mathrm{SO}_{2}$ to form new particles was $11 \mathrm{nmol} \mathrm{m}^{-3}$ for the clean Arctic atmosphere in fall. Sulfur dioxide concentrations in this study were higher than this threshold throughout the July 2014 campaign (average around $32 \mathrm{nmol} \mathrm{m}^{-3}$ ) except for 11 13 July. This is consistent with the measurements of Mungall et al. (2015), who reported high DMS concentrations in both the ocean and atmosphere during the same cruise. When $\delta^{34} \mathrm{~S}$ values for aerosol size fractions and $\mathrm{SO}_{2}$ are similar, then it is likely that local $\mathrm{SO}_{2}$ oxidation lead to substantial sulfate content. There are two periods where this is clearly the case and biogenic sulfate was dominant:

1. 11-13 July, with $\delta^{34} \mathrm{~S}$ values for $\mathrm{E}_{0.49-0.95 \mu \mathrm{m}}$ and $\mathrm{D}_{0.95-1.5 \mu \mathrm{m}}$ filters of +14.2 and $+13.1 \%$, respectively, and 
2. 13-15 July, with $\delta^{34} \mathrm{~S}$ values for $\mathrm{SO}_{2}, \mathrm{~F}_{<0.49 \mu \mathrm{m}}$ and $\mathrm{E}_{0.49-0.95 \mu \mathrm{m}}$ filters of $+16.7,+16.8$ and $+15.8 \%$, respectively.

In contrast, anthropogenic sulfate contributed to aerosol growth on 9-11 July with $\delta^{34} \mathrm{~S}$ values for $\mathrm{E}_{0.49-0.95 \mu \mathrm{m}}$ and

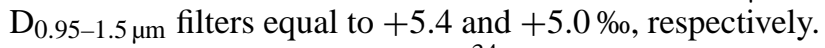

It is interesting to note that $\delta^{34} \mathrm{~S}$ values for $17-19$ July on the $\mathrm{E}_{0.49-0.95 \mu \mathrm{m}}$ filters $(0.49-0.95 \mu \mathrm{m})$ and $\mathrm{SO}_{2}$ indicate almost pure biogenic sulfur $\left(\delta^{34} \mathrm{~S}_{\mathrm{E}}=+17.8 \%, \delta^{34} \mathrm{~S}_{\mathrm{SO}_{2}}=\right.$ $+17.6 \%$ ). However, the $\delta^{34} \mathrm{~S}$ value for sulfate on the $\mathrm{F}_{<0.49 \mu \mathrm{m}}$ filters $(<0.49 \mu \mathrm{m})$ was lower $(+10.2 \%)$. This suggests that aerosols $<0.49 \mu \mathrm{m}(\mathrm{F})$ for this sampling period originated, in part, from anthropogenic sources, but aerosol growth from 0.49 to $0.95 \mu \mathrm{m}$ (E) was dominated by the oxidation of biogenic $\mathrm{SO}_{2}$ at this time.

\section{Conclusion}

Size-segregated aerosol sulfate concentrations were measured in the Arctic and subarctic during July 2014. Sulfate was apportioned between sea salt, biogenic and anthropogenic sources using sulfur isotopes. Around $85 \%$ of coarse-mode $(>0.95 \mu \mathrm{m})$ aerosol sulfate was from sea salt. However, there was little to no sea salt sulfate in fine aerosols $(<0.49 \mu \mathrm{m})$, and more than $97 \%$ of the sulfate in these aerosols was non-sea-salt. Approximately uniform non-seasalt sulfate concentrations were found for TOTAL sulfate $\left(130 \pm 21 \mathrm{ng} \mathrm{m}^{-3}\right)$ in the Arctic atmosphere. The dominant source for fine aerosols and $\mathrm{SO}_{2}$ was biogenic sulfur, arising from the oxidation of DMS, which is likely due to a high ocean-atmosphere gas exchange and the large ice-free surface in the Arctic during July (Levasseur, 2013).

A comparison of $\delta^{34} \mathrm{~S}$ values for fine $(<0.49 \mu \mathrm{m})$ aerosols and $\mathrm{SO}_{2}$ samples was used to show that the growth of preexisting fine particles occurred primarily due to the oxidation of $\mathrm{SO}_{2}$ from DMS during all sampling events except for two where a relatively high anthropogenic fraction in the smallest submicron size $(<0.49 \mu \mathrm{m}, \mathrm{F}$ filter $)$ was found $(15-17$ and 17-19 July). The dominance of ocean biogenic sources in fine-aerosol sulfate and the similarity of the sulfur isotope composition for $\mathrm{SO}_{2}$ and these fine particles highlight the contribution of marine life to the formation and growth of fine particles above the Arctic Ocean during the productive month of July.

Acknowledgements. This study was part of the NETCARE (Network on Climate and Aerosols: Addressing Key Uncertainties in Remote Canadian Environments) project and was supported by funding from NSERC. The authors would also like to thank the crew of the Amundsen and fellow scientists.

Edited by: B. Ervens

\section{References}

Andreae, M. O.: Ocean-atmosphere interactions in the global biogeochemical sulfur cycle, Mar. Chem., 30, 1-29, 1990.

Ayers, G. P. and Cainey, J. M.: The CLAW hypothesis: a review of the major developments, Environ. Chem., 4, 366-374, 2007.

Barnes, I., Hjorth, J., and Mihalopoulos, N.: Dimethyl sulfide and dimethyl sulfoxide and their oxidation in the atmosphere, Chem. Rev., 106, 940-975, 2006.

Bates, T. S., Charlson, R. J., and Gammon, R. H.: Evidence for climate role of marine biogenic sulphur, Nature, 329, 319-321, 1987.

Bates, T. S., Calhoun, J. A., and Quinn, P. K.: Variations in the methanesulfonate to sulfate molar ratio in submicrometer marine aerosol particles over the south Pacific ocean, J. Geophys. Res., 97, 9859-9865, 1992.

Bates, T. S., Anderson, T. L., Baynard, T., Bond, T., Boucher, O., Carmichael, G., Clarke, A., Erlick, C., Guo, H., Horowitz, L., Howell, S., Kulkarni, S., Maring, H., McComiskey, A., Middlebrook, A., Noone, K., O’Dowd, C. D., Ogren, J., Penner, J., Quinn, P. K., Ravishankara, A. R., Savoie, D. L., Schwartz, S. E., Shinozuka, Y., Tang, Y., Weber, R. J., and Wu, Y.: Aerosol direct radiative effects over the northwest Atlantic, northwest Pacific, and North Indian Oceans: estimates based on in-situ chemical and optical measurements and chemical transport modeling, Atmos. Chem. Phys., 6, 1657-1732, doi:10.5194/acp-6-1657-2006, 2006.

Bigg, E. K. and Leck, C.: Properties of the aerosol over the central Arctic Ocean, J. Geophys. Res., 106, 32101-32109, 2001.

Brioude, J., Arnold, D., Stohl, A., Cassiani, M., Morton, D., Seibert, P., Angevine, W., Evan, S., Dingwell, A., Fast, J. D., Easter, R. C., Pisso, I., Burkhart, J., and Wotawa, G.: The Lagrangian particle dispersion model FLEXPART-WRF version 3.1, Geosci. Model Dev., 6, 1889-1904, doi:10.5194/gmd-61889-2013, 2013.

Browse, J., Carslaw, K. S., Mann, G. W., Birch, C. E., Arnold, S. R., and Leck, C.: The complex response of Arctic aerosol to sea-ice retreat, Atmos. Chem. Phys., 14, 7543-7557, doi:10.5194/acp14-7543-2014, 2014.

Charlson, R. J., Lovelock, J. E., Andreae, M. O., and Warren, S. G.: Oceanic phytoplankton, atmospheric sulphur, cloud albedo and climate, Nature, 326, 655-661, 1987.

Elliott, S., Deal, C., Humphries, G., Hunke, E., Jeffery, N., Jin, M., Levasseur, M., and Stefels, J.: Pan-Arctic simulation of coupled nutrient-sulfur cycling due to sea ice biology: preliminary results, J. Geophys. Res., 117, G01016, doi:10.1029/2011JG001649, 2012.

Gabric, A. J., Qu, B., Matrai, P., and Hirst, A. C.: The simulated response of DMS production in the Arctic ocean to global warming, Tellus B, 57, 391-403, doi:10.1111/j.16000889.2005.00163.x, 2005.

Harris, E., Sinha, B., Hoppe, P., and Ono, S.: High-Precision Measurements of ${ }^{33} \mathrm{~S}$ and ${ }^{34} \mathrm{~S}$ Fractionation during $\mathrm{SO}_{2}$ Oxidation Reveal Causes of Seasonality in $\mathrm{SO}_{2}$ and Sulfate Isotopic Composition, Environ. Sci. Technol., 47, 12174-12183, 2013.

Hewitt, C. N. and Davison, B.: Field measurements of dimethyl sulphide and its oxidation products in the atmosphere, Philos. T. R. Soc. B, 352, 183-189, 1997.

IPCC: Climate Phenomena and their Relevance for Future Regional Climate Change, in: Climate Change 2013: The Physical Science 
Basis. Contribution of Working Group I to the Fifth Assessment Report of the Intergovernmental Panel on Climate Change, edited by: Stocker, T. F., Qin, D., Plattner, G.-K., Tignor, M., Allen, S. K., Boschung, J., Nauels, A., Xia, Y., Bex, V., and Midgley, P. M., Cambridge University Press, Cambridge, United Kingdom and New York, NY, USA, 1217-1308, 2013.

Jaeglé, L., Quinn, P. K., Bates, T. S., Alexander, B., and Lin, J.-T.: Global distribution of sea salt aerosols: new constraints from in situ and remote sensing observations, Atmos. Chem. Phys., 11, 3137-3157, doi:10.5194/acp-11-3137-2011, 2011.

Krouse, H., Grinenko, L., Grinenko, V., Newman, L., Forrest, J., Nakai, N., Tsuji, Y., Yatsumimi, T., Takeuchi, V., Robinson, B., Stewart, M., Gunatilaka, A., Plumb, L., Smith, J., Buzek, F., Cerny, J., Sramek, J., Menon, A., Iyer, G., Venkatasubramanian, V., Egboka, B., Irogbenachi, M., and Eligwe, C.: Stable Isotopes, Natural and Anthropogenic Sulphur in the Environment, Chapter, Case Studies and Potential Applications, Wiley, Chichester, 1991.

Leaitch, W. R., Sharma, S., Huang, L., Toom-Sauntry, D., Chivulescu, A., Macdonald, A. M., von Salzen, K., Pierce, J. R., Bertram, A. K., Schroder, J. C., Shantz, N. C., Chang, R. Y.-W., and Norman, A.-L.: Dimethyl sulfide control of the clean summertime Arctic aerosol and cloud, Elementa: Science of the Anthropocene, 1, 000017, doi:10.12952/journal.elementa.000017, 2013.

Leck, C. and Bigg, E. K.: Biogenic particles in the surface microlayer and overlaying atmosphere in the central Arctic Ocean during summer, Tellus B, 57, 305-316, 2005a.

Leck, C. and Bigg, E. K.: Source and evolution of the marine aerosol - A new perspective, Geophys. Res. Lett., 32, 1-4, 2005 b.

Levasseur, M.: Impact of Arctic meltdown on the microbial cycling of sulfur, Nat. Geosci., 6, 691-700, 2013.

Lewis, E. R. and Schwartz, S. E.: Sea salt Aerosol Production: Mechanisms, Methods, Measurements, and Models, 413 pp., American Geophysical Union, Washington, DC, 2004.

Li, S.-M. and Barrie, L. A.: Biogenic sulfur aerosol in the Arctic troposphere: 1. Contributions to total sulfate, J. Geophys. Res., 98, 613-620, 1993.

Matrai, P. A., Tranvik, L., Leck, C., Knulst, J. C.: Are high Arctic surface microlayers a potential source of aerosol organic precursors?, Mar. Chem., 108, 109-122, 2008.

Mungall, E. L., Croft, B., Lizotte, M., Thomas, J. L., Murphy, J. G., Levasseur, M., Martin, R. V., Wentzell, J. J. B., Liggio, J., and Abbatt, J. P. D.: Summertime sources of dimethyl sulfide in the Canadian Arctic Archipelago and Baffin Bay, Atmos. Chem. Phys. Discuss., 15, 35547-35589, doi:10.5194/acpd-15-355472015, 2015.

Najafi, M. R., Zwiers, F. W., and Gillett, N. P.: Attribution of Arctic temperature change to greenhouse-gas and aerosol influences, Nature Climate Change, 5, 246-249, 2015.

Nightingale, P. D., Liss P. S., and Schlosser. P.: Measurments of airsea gas transfer during an open ocean algal bloom, Geophys. Res. Lett., 27, 2117-2120, 2000.

Norman, A. L., Barrie, L. A., Toom-Sauntry, D., Sirois, A., Krouse, H. R., Li, S. M., and Sharma, S.: Sources of aerosol sulphate at Alert: apportionment using stable isotopes, J. Geophys. Res., 104, 11619-11631, 1999.

Norman, A. L., Belzer, W., and Barrie, L.: Insights into the biogenic contribution to total sulphate in aerosol and precipitation in the
Fraser Valley afforded by isotopes of sulphur and oxygen, J. Geophys. Res., 109, DO5311, doi:10.1029/2002JD003072, 2004.

Nriagu, L. O. and Coker, R. D.: Isotopic composition of sulfur in precipitation within the Great Lakes Basin, Tellus, 30, 365-375, 1978.

Patris, N., Delmas, R. J., Legrand, M., De Angelis, M., Ferron, F. A., Stièvenard, M., and Jouzel, J.: First sulfur isotope measurements in central Greenland ice cores along the preindustrial periods, J. Geophys. Res., 107, D000672, doi:10.1029/2001JD000672, 2002.

Quinn, P. K. and Bates, T. S.: The case against climate regulation via oceanic phytoplankton sulfur emissions, Nature, 480, 51-56, doi:10.1038/nature10580, 2011.

Quinn, P. K., Miller, T. L., Bates, T. S., Ogren, J. A., Andrews, E., and Shaw, G. E.: A 3-year record of simultaneously measured aerosol chemical and optical properties at Barrow, Alaska, J. Geophys. Res., 107, AAC 8-1-AAC 8-15, doi:10.1029/2001JD001248, 2002.

Quinn, P. K., Bates, T. S., Schulz, K., and Shaw, G. E.: Decadal trends in aerosol chemical composition at Barrow, Alaska: 19762008, Atmos. Chem. Phys., 9, 8883-8888, doi:10.5194/acp-98883-2009, 2009.

Quinn, P. K., Collins, D. B., Grassian, V. H., Prather, K. A., and Bates, T. S.: Chemistry and Related Properties of Freshly Emitted Sea Spray Aerosol, Chem. Rev., 115, 4383-4399, doi:10.1021/cr500713g, 2015.

Rempillo, O., Seguin, A. M., Norman, A.-L., Scarratt, M., Michaud, S., Chang, R., Sjostedt, S., Abbatt, J., Else, B., Papakyriakou, T., Sharma, S., Grasby, S., and Levasseur, M.: Dimethyl sulfide air-sea fluxes and biogenic sulfur as a source of new aerosols in the Arctic fall, J. Geophys. Res.-Atmos., 116, D00S04, doi:10.1029/2011JD016336, 2011.

Rees, C. E., Jenkins, W. J., and Monster, J.: Sulphur isotopic composition of Ocean water sulfate, Geochim. Cosmochim. Ac., 42, 377-381, 1978.

Richards, S. R., Rudd, J. W. M., and Kelley, C. A.: Organic volatile sulfur in lakes ranging in sulfate and dissolved salt concentration over five orders of magnitude, Limnol. Oceanogr., 39, 562-572, 1994.

Saltzman, E. S., Brass, G. W., and Price, D. A.: The mechanism of sulfate aerosol formation: chemical and sulfur isotopic evidence, Geophys. Res. Lett., 10, 513-516, 1983.

Sanusi, A. A., Norman, A. L., Burridge, C., Wadleigh, M., and Tang, W. W.: Determination of the S isotope composition of methanesulfonic acid, Anal. Chem., 78, 4964-4968, 2006.

Savoie, D. L., Arimoto, R., Keene, W. C., Prospero, J. M., Duce, R. A., and Galloway, J. N.: Marine biogenic and anthropogenic contributions to non-sea salt sulfate in the marine boundary layer over the North Atlantic Ocean, J. Geophys. Res., 107, 43564376, 2002.

Seguin, A. M., Norman, A. L., Eaton, S., Wadleigh, M., and Sharma, S.: Elevated biogenic sulphur dioxide concentrations over the North Atlantic, Atmos. Environ., 44, 1139-1144, 2010.

Seguin, A. M., Norman, A.-L., Eaton, S., and Wadleigh, M.: Seasonality in size segregated biogenic, anthropogenic and sea salt sulfate aerosols over the North Atlantic, Atmos. Environ., 45, 6947-6954, 2011.

Sharma, S., Chan, E., Ishizawa, M., Toom-Sauntry, D., Gong, S. L., Li, S. M., Tarasick, D. W., Leaitch, W. R., Norman, A., Quinn, P. 
K., Bates, T. S., Levasseur, M., Barrie, L. A., and Maenhaut, W.: Influence of transport and ocean ice extent on biogenic aerosol sulfur in the Arctic atmosphere, J. Geophys. Res., 117, D12209, doi:10.1029/2011JD017074, 2012.

Shindell, D.: Estimating the potential for twenty-first century sudden climate change, Philos. T. R. Soc. A, 365, 2675-2694, 2007.

Sirois, A. and Barrie, L. A.: Arctic lower tropospheric aerosol trends and composition at Alert, Canada: 1980-1995, J. Geophys. Res., 104, 11599-11618, 1999.

Stone, R. S., Sharma, S., Herber, A., Eleftheriadis, K., and Nelson, D. W.: A characterization of Arctic aerosols on the basis of aerosol optical depth and black carbon measurements, Elementa: Science of Anthropocene, 2, 000027 , doi:10.12952/journal.elementa.000027, 2014.

Thornton, D. C., Bandy, A. R., and Driedger III, A. R.: Sulfur dioxide in the North American Arctic, J. Atmos. Chem., 9, 331-346, 1989.
Tisch Environmental, Inc.: Series 230 High Volume Cascade Impactors; Multi-Stage Particulate Size Fractionator, Operations Manual, Ohio, USA, 2004.

Wentworth, G. R., Murphy, J. G., Croft, B., Martin, R. V., Pierce, J. R., Côté, J.-S., Courchesne, I., Tremblay, J.-É., Gagnon, J., Thomas, J. L., Sharma, S., Toom-Sauntry, D., Chivulescu, A., Levasseur, M., and Abbatt, J. P. D.: Ammonia in the summertime Arctic marine boundary layer: sources, sinks, and implications, Atmos. Chem. Phys., 16, 1937-1953, doi:10.5194/acp-16-19372016, 2016.

Yin, F., Grosjean, D., and Seinfeld, J. H.: Photooxidation of dimethyl sulfide and dimethyl disulfide. I: mechanism development, J. Atmos. Chem., 11, 309-364, 1990. 